\title{
PENGARUH PENGAWASAN TERHADAP EFEKTIVITAS KERJA KARYAWAN PADA PT. CAHAYA ENIM
}

\author{
Heryati *)
}

\begin{abstract}
ABSTRAK
Perumusan masalah dalam penelitian ini adalah apa ada pengaruh pengawasan terhadap efektivitas kerja karyawan pada PT. Cahaya Enim. Sedangkan tujuan penelitian ini untuk mengetahui apakah ada pengaruh pengawasan terhadap efektivitas kerja karyawan pada PT. Cahaya Enim. Populasi dalam dalam penelitian ini adalah karyawan tetap yang berjumlah 34 orang dan keseluruhan diambil sebagai sampel penelitian. Teknik analisis yang digunakan dalam penelitian ini adalah regresi linier sederhana, analisis korelasi dan uji hipotesis t.

Hasil analisis yang diperoleh dengan menggunakan rumus regresi linier sederhana yaitu $Y^{\prime}=9,476+$ $0,613 \mathrm{X}$, dengan korelasi didapat nilai $\mathrm{R}=0,616$. ini berarti terdapat pengaruh yang kuat antara pengawasan terhadap efektivitas kerja karyawan pada PT. Cahaya Enim, dengan koefisien determinasi diperoleh nilai $=0,417$. Hal ini berarti variabel efektivitas kerja karyawan dipengaruhi oleh variabel pengawasan hanya sebesar $41,7 \%$, sedangkan sisanya dipengaruhi oleh variabel lain yang tidak diteliti. Dari hasil uji t didapat nilai thitung 4,782 $\geq$ tabel 2,037, maka dapat disimpulkan bahwa Ha diterima berarti ada pengaruh positif dan signifikan antara pengawasan terhadap efektivitas kerja karyawan pada PT. Cahaya Enim.
\end{abstract}

\section{Kata Kunci : Pengawasan, Efektivitas kerja}

\section{A. Latar Belakang}

Setiap organisasi atau perusahaan tentu mengharapkan agar kegiatan aktivitas perusahaan dapat mencapai sasaran sebagaimana yang telah ditetapkan. Tujuan aktivitas tersebut adalah untuk kelangsungan hidup perusahaan itu sendiri. Untuk mencapai tujuan organisasi, perusahaan harus dapat menjalankan fungsi-fungsi manajemen. Berkaitan dengan gerak laju perkembangan dunia usaha, peran manajemen bagi suatu perusahaan merupakan suatu proses yang terpadu. Peranan tujuan meliputi bagaimana kegiatan dilakukan dengan menggunakan sumber daya yang ada agar dapat mencapai tujuan yang telah ditetapkan. Salah satu fungsi manajemen adalah pengawasan yang merupakan proses untuk mengukur pelaksanaan dan memberikan panduan ke arah sasaran yang berlaku sekarang serta memberikan panduan ke arah sasaran yang telah ditetapkan sebelumnya.

Seorang pemimpin tentu akan berusaha untuk melakukan pembinaan terhadap karyawan berdasarkan peraturan yang ada. Peraturan yang dibuat dapat membentuk sikap karyawan dalam bekerja dan menimbulkan suasana yang tertib, sehingga pencapaian tujuan yang akan dicapai terlaksana dengan baik.

Agar suatu badan usaha dapat berhasil dalam mencapai tujuan yang ditentukan, maka pengawasan memegang peranan penting dalam membina karyawan. Pekerjaan itu harus dilaksanakan dengan baik sebab dalam bekerja diharapkan sebagian besar peraturan-peraturan dari perusahaan dapat ditaati oleh karyawan, sehingga pekerjaan yang dilakukan akan lebih efektif. Apabila pengawasan tidak dilakukan, maka karyawan yang dulunya rajin, disiplin dan produktif akan berubah menjadi pemalas. Hal ini dapat berdampak buruk terhadap kemajuan perusahaan, sehingga bila tidak diambil tindakan tegas, maka dapat mengakibatkan hasil kerja tidak efektif.

Pengawasan merupakan bagian
dari fungsi menajemen yang

\footnotetext{
*) Dosen Tetap Fakultas Ekonomi UPGRI Palembang
} 
diharapkan mampu menciptakan efisiensi dan efektifitas kerja yang dilakukan oleh para pegawai. Dengan pengawasan yang baik diharapkan akan berkurangnya kesalahan dan penyimpangan yang terjadi. Tugas seorang pemimpin adalah untuk mengawasi para pegawai yang ada dalam lingkup organisasinya.

Pengawasan yang efektif akan menciptakan disiplin dan etos kerja karyawan menjadi lebih baik, serta memacu efektivitas kerja yang tinggi. Pengawasan yang efektif dari seorang manajer/pimpinan maka semangat kerja akan timbul dan para karyawan akan bekerja dengan rajin dan bertanggung jawab sehingga efektivitas kerja karyawan dapat meningkat dengan sendirinya.

Berdasarkan uraian diatas, maka penulis tertarik untuk melakukan penelitian dengan judul "Pengaruh Pengawasan Terhadap Efektivitas Kerja Karyawan Pada PT. Cahaya Enim".

\section{B. Masalah Penelitian}

Berdasarkan latar belakang di atas, maka dapat dirumuskan permasalahan sebagai berikut: "Apa ada pengaruh pengawasan terhadap efektivitas kerja karyawan pada PT. Cahaya Enim?

\section{Tujuan Penelitian}

Untuk mengetahui pengaruh pengawasan terhadap efektivitas kerja karyawan pada PT. Cahaya Enim.

\section{Konsep Teoritis}

1. Pengawasan

\subsection{Pengertian Pengawasan}

Pengawasan merupakan salah satu unsur dalam fungsi primer kegiatan adminitrasi yang dalam urutan penulisannnya selalu berada dibelakang. Kondisi ini sering dihubungkan dengan penempatannya sebagai bagian akhir dari keseluruhan adminitrasi dan kegiatan pengendalian kerjasama sejumlah manusia untuk mencapai tujuan bersama.

Winardi dalam Kadir (2006: 11) pengawasan berarti mendeterminasi apa yang telah dilaksanakan, maksudnya pengevaluasi prestasi kerja dan apabila perlu menetapkan tindakan-tindakan korektif sehingga hasil dari pekerjaan sesuai dengan rencana.

Sedangkan Siagian (2008 : 139) menyebutkan bahwa pengawasan adalah suatu bentuk pengammatan yang umumnya dilakukan secara menyeluruh, dengan jalan mengadakan perbandingan antara yang dikonstatir dan yang seharusnya dilaksanakan.

Tujuan utama dari pengawasan ialah mengusahakan agar perencanaan menjadi kenyataan. Oleh karena itu, agar suatu sistem pengawasan lebih efektif manajer harus dapat segera melaporkan penyimpangan-penyimpangan yang terjadi sehingga berdasarkan penyimpangan-penyimpangan itu dapat diambil tindakan. Hal ini bertujuan agar pelaksanaan rencana keseluruhan benar-benar dapat sesuai atau dapat mendekati apa yang direncanakan. Dari pengertian pengawasan yang telah dikemukakan diatas, pengawasan dapat didefinisikan sebagai suatu alat pembimbing dan mengendali pelaksanaan rencana yang telah ditetapkan yang dapat mempermudah atau meringankan tugas-tugas para pelaksana.

Pengawasan merupakan alat pengendali tindakan, berarti pengawasan tidak hanya mengendalikan, akan tetapi juga merupakan aspek penilaian, apakah kegiatan yang dicapai sesuai dengan 
tujuan rencana yang telah ditetapkan sebelumnya atau tidak.

Maka dari itu pengawasan mengandung tiga aspek, Handoko (2009: 361) yaitu:

a. Sesuai dengan rencana yang telah ditetapkan.

b. Sesuai dengan peraturan perundang-undangan dan ketentuan-ketentuan yang berlaku.

c. Memenuhi prinsip efesiensi (daya guna) dan efektivitas (hasil guna).

\subsection{Langkah-Langkah Pengawasan}

Handoko (2009: 362-365)

mengemukakan bahwa langkahlangkah pengawasan meliputi empat langkah sebagai berukut :

a. Menetapkan Standar

Standar merupakan sesuatu yang dianggap nilainya sehingga dapat dipakai sebagai ukuran nilai standar. Standar ukuran dari pelaksanaan pekerjaan efektif dalam rangka pencapaian tujuan.

b. Menilai dan mengukur pekerjaan yang sedang dilaksanakan, langkah ini dilakukan melalui laporan atau pengamatan secara langsung pada unit-unit kerja.

c. Melaksanakan perbandingan antara hasil pengukuran dengan standar. Langkah ini dimaksud untuk mengetahui apakah terdapat perbedaan antara hasil pengkuran dengan standar, jika terdapat perbedaaan perlu diadakan perbaikan atau tidak.

d. Mengusahakan tindakan perbaikan Langkah ini merupakan kelanjutan langkah-langkah sebelumnya, dimana apabila diketahui adanya perbedaan, maka langkah terakhir dilakukan perbaikan.

\section{Efektivitas Kerja}

\subsection{Pengertian Efektivitas}

Konsep efektivitas

digunakan sebagai indikator keberhasilan suatu organisasi. Konsep ini menekankan sejauh mana tujuan dapat dicapai secara optimal. Handoko (2009 : 7), mengemukakan efektivitas adalah kemampuan untuk memilih tujuan yang tepat atau peralatan yang tepat untuk pencapaian tujuan yang ditetapkan. Winandi (2008: 19) memaparkan bahwa efektivitas adalah tingkat hingga di mana suatu tindakan atau aktivitas mencapai tujuan yang ditetapkan. Efektivitas suatu yang menunjunkan tingkat keberhasilan kegiatan manajemen di dalam mencapai tujuan.

Dari uraian tersebut dapat disimpulkan bahwa efektivitas merupakan kemampuan pemimpin efektivitas kerja dalam kaitannya dengan konsekuensi-konsekuensi dari tindakan-tindakan pemimpin tersebut bagi para shareholder dan para stakeholder organisasi lainnya. Namun demikian kinerja dan pertumbuhan dari sekelompok atau organisasi dari pemimpin tersebut, kepuasan pengikut dengan pemimpinnya, komitmen dari para pengikut terhadap sasaran kelompok, kesejahteraan psikologis dan pengembangan para pengikut, mempertahankan status tinggi pemimpin, dan kemajuan pemimpin ke posisi kekuasaan yang lebih tinggi di dalam organisasi.

\subsection{Indikator Mengukur Efektivitas Kerja \\ Menurut Gibson (2005:32-34))} disebutkan hahwa indikator untuk mengukur efektivitas organisasi adalah

a) Produksi (Produksi)

Produksi menggambarkan kemampuan organisasi untuk memproduksi jumlah dan mutu output yang sesuai dengan permintaan lingkungan. Dalam kaitannya dengan pengukuran efektifitas sebuah instansi 
pemerintah, tentunya parameter yang digunakan adalah seberapa optimal pelaksanaan tugas atau pelayanan kepada masyarakat serta seberapa besar tingkat kepuasan masyarakat yang dilayani.

b) Efisiensi (Efficiency)

Konsep ini didefinisikan sebagai angka perbandingan (rasio) antara output dan input, Kriteria ini memusatkan perhatian pada seturuh siklus input-proses-output, namun demikian kriteria ini menekankan unsur input dan proses. Ukuran efisiensi meliputi penggunaan waktu dengan sebaikbaiknya, periode waktu mesin tidak aktif dan lain sebagainya. Jelaslah bahwa ukuran efisiensi harus dinyatakan dalam perbandingan; perbandingan antara biaya yang telah dikeluarkan dengan output atau dengan waktu merupakan bentuk umum dari ukuran ini.

c) Kepuasan (Satisfaction)

Penyusunan konsep organisasi sebagai suatu sistem sosial mengharuskan kita memperhatikan keuntungan yang diterima oleh para pengurusnya maupun pelanggannya. Kepuasan dan semangat kerja adalah istilah yang serupa, yang menunjukkan sampai seberapa jauh organisasi memenuhi kebutuhan para pegawai atau pengurusnya. Ukuran kepuasan meliputi sikap pegawai, pergantian pegawai (turnover), kemangkiran (absenteeism), keterlambatan, dan keluhan.

d) Adaptasi (Adaptiveness)

Kemampuan adaptasi adalah sampai seberapa jauh organisasi dapat menanggapi perubahan intern dan ekstern. Kriteria ini berhubungan dengan kemampuan manajemen untuk menduga $\begin{array}{lcr}\text { adanya } & \text { perubahan } & \text { dalam } \\ \text { lingkungan } & \text { maupun } & \text { dalam } \\ \text { organisasi } & \text { itu sendiri. } & \text { Jika } \\ \text { organisasi } & \text { tidak } & \text { dapat } \\ \text { menyesuaikan } & \text { diri, } & \text { maka } \\ \text { kelangsungan } & \text { hidupnya } & \text { akan }\end{array}$ terancam. Dari berbagai pendapat di atas, indikator yang digunakan oleh penulis untuk mengukur tingkat efektivitas kerja pegawai di Kantor Dinas Pendidikan Kabupaten Semarang adalah : produksi, kepuasan kerja, efisiensi dan prestasi kerja. Hal tersebut karena kemampuan adaptasi merupakan gambaran sampai seberapa jauh suatu organisasi dapat menyesuaikan diri dengan perubahan yang terjadi baik intern maupun ekstern. Sementara Gibson (2005 : 33) mengemukakan bahwa tidak ada ukuran khusus dan nyata mengenai kemampuan menyesuaikan diri.

\section{Kerangka Pemikiran}

Secara ringkas kerangka pemikiran yang mendasari penelitian ini diilustrasikan kedalam bagan berikut ini :

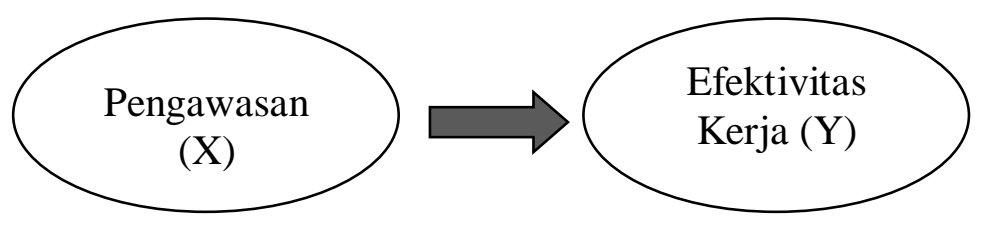

Gambar 1. Kerangka berfikir

\section{Hipotesis penelitian}

Hipotesis yang diajukan dalam penelitian ini adalah diduga adanya Pengaruh Pengawasan Terhadap Efektivitas Kerja Karyawan Pada PT. Cahaya Enim. 


\section{E. Metode Penelitian}

1. Variabel Penelitian

Variabel dalam penelitian ini adalah terdiri variabel bebas (independen) yang disebut dengan variabel $\mathrm{X}$, merupakan variabel yang tidak tergantung dengan variabel lainnya. Variabel $X$ dalam penelitian ini adalah pengawasan dan variabel terikat (Dependen) yang disebut dengan variabel $\mathrm{Y}$, merupakan variabel yang terantung atau terpengaruh oleh variabel lainnya. Variabel $\mathrm{Y}$ dalam penelitian ini adalah efektivitas kerja karyawan.

\section{Defenisi Operasional Variabel}

a. Pengawasan merupakan suatu proses yang dilakukan untuk memastikan seluruh rangkaian kegiatan yang telah direncanakan, diorganisasikan, dan diimplementasikan bisa berjalan sesuai dengan target yang diharapkan sekalipun berbagai perubahan terjadi dalam lingkungan dunia bisnis yang dihadapi, dengan indikator menetapkan standar, menilai dan mengukur pelaksanaan pekerjaan, melaksanakan perbandingan antara hasil pengukuran dengan standar dan mengusahakan tindakan perbaikan.

b. Efektivitas Kerja Karyawan merupakan kemampuan untuk memilih tujuan yang tepat atau peralatan yang tepat untuk pencapaian tujuan yang ditetapkan, dengan indikator produksi (produksi), efisiensi (efficiency), kepuasan (satisfaction) dan adaptasi (adaptiveness)

\section{Populasi dan Sampel}

Populasi dalam penelitian ini adalah jumlah keseluruhan karyawan tetap pada PT. Cahaya Enim yang berjumlah 34 Orang Karyawan.

Penelitian ini menggunakan metode sensus, yaitu mendata keseluruhan populasi yang ada untuk dijadikan sampel. Berdasarkan sensus dilapangan, maka sampel dalam penelitian ini sebanyak 34 orang karyawan pada PT. Cahaya Enim.

\section{Teknik Pengumpulan Data}

Sumber data yang digunakan dalam penelitian ini , adalah data primer dan data sekunder.

a. Data Primer adalah data yang diperoleh secara langsung dari perusahaan. Data asil yang dikumpulkan sendiri oleh periset untuk menjawab masalah risetnya secara khusus.

b. Data Sekunder merupakan data yang telah diolah oleh pihak pengumpul data primer yang disajikan sebagai informasi yang dapat mendukung suatu penelitian. Data sekunder ini dapat diperoleh dari berbagai literatur, referensi, dan panduan yang ada dengan teknik pengumpulan data studi dokumenter, yaitu metode pengumpulan data dengan melihat dokumen-dokumen yang ada pada PT Cahaya Enim .

\section{Metode Pengumpulan Data}

Teknik pengumpulan data terdiri dari sebagai berikut:.

a. Angket (kuesioner), adalah sejumlah pertanyaan tertulis yang dugunakan untuk memperolah informasi dari responden dalam arti laporan tentang hal-hal yang ingin diketahui.

b. Dokumentasi adalah barangbarang tertulis seperti buku-buku, majalah, dokumen, peraturanperaturan, notulen rapat, catatan harian, dan lain sebagainya. 


\section{Uji Validitas dan Reliabilitas Instrumen}

Uji validitas untuk dapat digunakan pendapat dari ahli (judgmet experts). Dalam hal ini setelah instrumen dikontruksi tenteng aspekaspek yang akan diukur dengan berlandaskan teori tertentu Sugiyono (2010: 352)

Pengujian reliabilitas instrumen dapat dilakukan secara eksternal maupum internal. Secara eksternal pengujian dapat dilakukan dengan test-retest (stability), equivalent, dan gabungan keduanya. Dan secara internal reliabilitas instrumen dapat diuji dengan menganalisis konsistensi butir-butir yang ada p;ada instrumen dengan teknik tertentu Sugiyono (2010: 354).

\section{Teknik Analisis Data}

Teknik analisis data yang penulis gunakan yakni teknik analisis data kuantitatif, yaitu suatu metode analisis yang menggunakan perhitungan angka-angka untuk pengambilan keputusan dengan teknik analisis Regresi Sederhana. Penelitian ini mengguakan skala Likert's yang digunakan untuk mengukur tanggapan atau responden seseorang tentang objek social. Sugiyono (2010: 86). Responden diminta memberikan tanggapan terhadap pertanyaan dalam kuesioner kemudian masing-masing tanggapan respondon diberikan skor.
F. Hasil Penelitian dan
Pembahasan
1. Pengujian Kuesioner
Untuk mengetahui bahwa instrumen penelitian ini merupakan alat ukur yang akurat dan dapat dipercaya maka diperlukan pengujian data. Pengujian data yang digunakan meliputi uji validitas dan uji realibilitas. Untuk melakukan uji validitas dan uji realibilitas, penulis menggunkan program IBM Statisctical Package for Social Science (SPSS) versi 15.0. Variabel yang diuji adalah variabel bebas (independent) yaitu Pengawasan dan variabel terikat (dependent) yaitu Efektivitas kerja. Maka hasil uji validitas dan uji reliabilitas adalah sebagai berikut:

\section{a. Uji Validitas}

Uji validitas digunakan untuk mengukur derajat ketepatan dalam item-item pertanyaan suatu kuesioner, dikatakan valid apabila pertanyaan tersebut mampu untuk mengungkapkan sesuatu yang akan diukur oleh kuesioner tersebut. Suatu data dapat dikatakan valid apabila nilai korelasi hitung ( $r$ hitung) data tersebut melebihi nilai korelasi tabelnya. Nilai $r$ hitung adalah nilai-nilai yang berada dalam kolom "Corrected Item Tabel Correlation (CITC)" pada lembar output SPSS. Apabila nilai CITC $>$ nilai $r$ tabel maka variabel tersebut valid. Setelah dilakukan pengolahan data diperoleh hasil seperti yang dapat dilihat pada tabel berikut ini : 
Tabel 1. Hasil Uji Validitas

\begin{tabular}{|c|c|c|c|c|c|}
\hline Variabel & Item & $\begin{array}{c}\text { PValue } \\
\mathbf{0 . 0 5}\end{array}$ & Signifikan & $\begin{array}{c}\text { Pearson } \\
\text { Correlation }\end{array}$ & Keterangan \\
\hline \multirow{4}{*}{$\begin{array}{c}\text { Pengawasan } \\
(\mathrm{X})\end{array}$} & Pertanyaan 1 & 0,000 & 0,05 & 0,872 & Valid \\
\cline { 2 - 6 } & Pertanyaan 2 & 0,023 & 0,05 & 0,388 & Valid \\
\cline { 2 - 6 } & Pertanyaan 3 & 0,000 & 0,05 & 0,852 & Valid \\
\cline { 2 - 6 } & Pertanyaan 4 & 0,000 & 0,05 & 0,923 & Valid \\
\cline { 2 - 6 } & Pertanyaan 5 & 0,000 & 0,05 & 0,900 & Valid \\
\cline { 2 - 6 } & Pertanyaan 6 & 0,000 & 0,05 & 0,887 & Valid \\
\hline \multirow{3}{*}{ Kfektivitas } & Pertanyaan 1 & 0,000 & 0,05 & 0,926 & Valid \\
\cline { 2 - 6 } & Pertanyaan 2 & 0,004 & 0,05 & 0,486 & Valid \\
\cline { 2 - 6 } & Pertanyaan 3 & 0,000 & 0,05 & 0,912 & Valid \\
\cline { 2 - 6 } & Pertanyaan 4 & 0,000 & 0,05 & 0,906 & Valid \\
\cline { 2 - 6 } & Pertanyaan 5 & 0,000 & 0,05 & 0,909 & Valid \\
\cline { 2 - 6 } & Pertanyaan 6 & 0,000 & 0,05 & 0,836 & Valid \\
\hline
\end{tabular}

Sumber : Hasil Uji Validitas Variabel penjualan dengan SPSS versi 17.0

Dari hasil perhitungan uji validitas di atas untuk variabel pengawasan dan efektivitas kerja karyawan dari masing-masing 6 butir pertanyaan diketahui semua butir pertanyaan memiliki nilai $r_{\text {hitung }}$ lebih besar dari $r$ tabel 0,339 , sehingga dinyatakan valid. Maka dapat disimpulkan semua butir pertanyaan pada instrumen variable pengawasan dan efektivitas kerja karyawan tersebut dapat dijadikan sebagai alat ukur dalam analisis selanjutnya

\section{b. Uji Reliabilitas}

Uji Reliabilitas adalah indeks yang menunjukkan sejauh mana alat pengukur dapat diandalkan. Uji reliabilitas digunakan untuk mengukur ketetapan atau kejituan suatu instrumen. Kuesioner dikatakan reliabel (andal) jika nilai $r$ alpha positif dan $r$ alpha $>0,6$. Artinya butir pertanyaan atau variabel tersebut adalah dapat dipercaya (reliable).

\section{Tabel 2. Hasil Uji Reliabilitas}

\begin{tabular}{|l|c|c|}
\hline \multicolumn{1}{|c|}{ Variabel } & r Alpha & KetR. \\
\hline Pengawasan $(\mathrm{X})$ & 0,900 & Reliabel \\
\hline Efektivitas kerja $(\mathrm{Y})$ & 0,911 & Reliabel \\
\hline
\end{tabular}

Sumber : Diolah dari data kuesioner

Berdasarkan Tabel 2. terlihat bahwa nilai alpha lebih besar dari 0,6. Nilai alpha pengawasan $(X)$ yaitu 0,900 dan nilai alpha Efektivitas kerja (Y) yaitu 0,911 . Hal ini artinya data yang dipergunakan telah layak digunakan pada analisis selanjutnya.

\section{Uji Analisis Regresi}

a. Uji Regresi Linier Sederhana

Analisis regresi linier sederhana menggunakan SPSS versi 15.0 for windows yaitu dengan hasil :

Tabel 3. Hasil Uji Regresi Liner Sederhana

\begin{tabular}{|c|c|c|c|}
\hline \multicolumn{4}{|c|}{ Coefficients } \\
\hline & Unstandardize & Coefficients & $\begin{array}{l}\text { Standardized } \\
\text { Coefficients }\end{array}$ \\
\hline Model & $\mathrm{B}$ & Std. Error & Beta \\
\hline $\begin{array}{ll}1 & \text { (Constant) } \\
& \text { Pengawas an }(X)\end{array}$ & $\begin{array}{r}9,476 \\
613\end{array}$ & $\begin{array}{r}3,141 \\
128\end{array}$ & 646 \\
\hline
\end{tabular}

a. Dependent Variable: Efektivitas Kerja ( $Y$ )

Sumber : Hasil Pengolahan Data dengan SPSS Versi 15.00 
Persamaan regresinya adalah sebagai berikut:

$Y^{\prime}=a+b X$

$Y=9,476+0,613 X$

Konstanta sebesar 9,476

artinya jika pengawasan $(X)$ nilainya adalah 0, maka efektivitas kerja karyawan ( $Y$ ) nilainya sebesar 9,476. Sedangakan koefisien regresi variabel pengawasan (X) sebesar 0,613 artinya jika pengawasan mengalami kenaikan sebesar 1, maka efektivitas kerja karyawan (Y) akan mengalami peningkatan sebesar 0,613. Koefisien bernilai positif artinya ada pengaruh positif antara pengawasan dengan efektivitas kerja karyawan, semakin baik pengawasan yang dilakukan maka akan meningkatkan efektivitas kerja karyawan.

\section{b. Uji Koefisien korelasi sederhana}

Tabel 4. Model Summary

Model Summary

\begin{tabular}{|l|r|r|r|r|}
\hline Model & \multicolumn{1}{|c|}{$\mathrm{R}$} & R Square & $\begin{array}{c}\text { Adjusted } \\
\text { R Square }\end{array}$ & $\begin{array}{r}\text { Std. Error of } \\
\text { the Estimate }\end{array}$ \\
\hline 1 &, $646^{\mathrm{a}}$ &, 417 &, 399 & 2,998 \\
\hline
\end{tabular}

a. Predictors: (Constant), Implementasi Anggaran Berbas is Kinerja $(X)$

Sumber : Hasil Pengolahan Data dengan SPSS Versi 15.00

Menurut Sugiyono (2010 : 231) pedoman untuk memberikan interprestasi koefisien korelasi sebagai berikut :

$0,00-0,199=$ Sangat rendah

$0,20-0,399=$ rendah

$0,40-0,599=$ sedang

$0,60-0,799=$ kuat

$0,80-1,000=$ sangat kuat

Nilai korelasi $(R)$ yaitu sebesar

0,646 berarti berada pada range 0,60 0,799 . Hal tersebut berarti bahwa korelasi pengawasan $(X)$ terhadap efektivitas kerja karyawan (Y) adalah kuat dan berbanding lurus. Maksudnya jika ada peningkatan terhadap pengawasan $(X)$, maka akan diikuti juga dengan peningkatan efektivitas kerja karyawan ( $Y$ ) dengan berarti. Begitu juga sebaliknya, jika ada penurunan terhadap pengawasan $(X)$, maka juga akan diikuti dengan penurunan efektivitas kerja karyawan (Y) dengan tingkat hubungann kuat.

Dalam analisis koefisien korelasi terdapat koefisien determinasi $\left(r^{2}\right)$ yang besarnya adalah kuadrat dari koefisien korelasi ( $r$ ), koefisien ini disebut koefisien penentu. Dari hasil pengolahan data melalui program SPSS diperoleh nilai determinasi $r^{2}=$ 0,417. Hal ini memberikan makna bahwa variabel pengawasan hanya mampu menjelaskan perubahan terhadap variabel efektivitas kerja karyawan sebesar 41,7\%, sedangkan sisanya dijelaskan oleh variabelvariabel lain yang tidak termasuk dalam penelitian ini atau error (e).

\section{Uji Hipotesis (Uji t)}

Tabel 5. Uji t

\begin{tabular}{|c|c|c|c|}
\hline \multicolumn{4}{|c|}{ Coefficients $^{a}$} \\
\hline & & $t$ & Sig. \\
\hline & (Constant) & $\overline{3,016}$ & ,005 \\
\hline & Pengawasan $(X)$ & 4,782 &, 000 \\
\hline
\end{tabular}

a. Dependent Variable:Efektivitas Kerja (Y)

Setelah diperoleh hasil perhitungan koefisien korelasi antara pengawasan dan efektivitas kerja karyawan, maka dilakukan uji hipotesis dengan langkah-langkah sebagai berikut :

1) Menentukan hipotesis

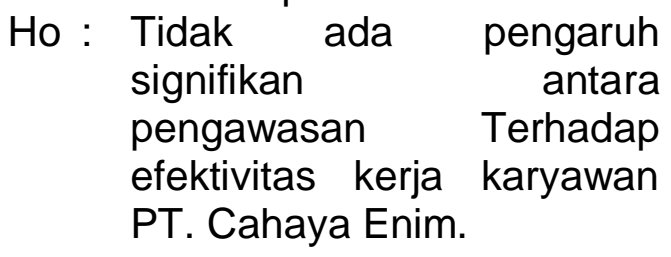


$\mathrm{Ha}$ : Ada pengaruh signifikan antara pengawasan Terhadap efektivitas kerja karyawan PT. Cahaya Enim.

2) Menentukan tingkat signifikansi

Tingkat signifikansi menggunakan alpha 5\% (signifikansi 5\% atau 0,05 adalah ukuran standar yang sering digunakan dalam penelitian).

3) Menentukan tabel

Tabel distribusi t dicari pada alpha $5 \%: 2=2,5 \%$ dengan derajad kebebasan (df) n-k-1 atau 34-1-1 = 32 (n adalah jumlah kasus dan $k$ adalah jumlah variable independen). Hasil diperoleh untuk $t_{\text {tabel }}$ sebesar 2,037 (table t).

4) Kriteria Pengujian

- Ho diterima Ha ditolak jika thitung $<$ tabel$_{\text {, artinya bahwa tidak ada }}$ pengaruh signifikan antara pengawasan Terhadap efektivitas kerja karyawan PT. Cahaya Enim.

- Ho ditolak Ha diterima jika thitung $>$ tabel, artinya bahwa ada pengaruh signifikan antara pengawasan Terhadap efektivitas kerja karyawan PT. Cahaya Enim.

5) Kesimpulan

Berdasarkan tabel 5 di atas, dapat dilihat bahwa nilai thitung untuk variabel pengawasan (X) adalah sebesar 4,782, hal ini berarti thitung $(4,782)>t_{\text {tabel }}(2,037)$, oleh karena itu Ho ditolak dan $\mathrm{Ha}$ diterima, maka terdapat pengaruh yang signifikan antara pengawasan Terhadap efektivitas kerja karyawan PT. Cahaya Enim.

\section{G. Kesimpulan Dan Saran \\ 1. Kesimpulan}

Berdasarkan analisis data yang telah dilakukan dan pembahasan yang diperoleh, maka dapat disimpulkan:

a. Terdapat pengaruh yang signifikan antara pengawasan terhadap efektivitas kerja karyawan PT. Cahaya Enim. Hal ini berdasarkan hasil pengujian hipotesis yang diperoleh dimana nilai thitung lebih besar dari nilai $t_{\text {tabel }}(4,782>2,037)$ maka keputusannya adalah menerima hipotesis alternatif $(\mathrm{Ha})$ dan menolak hipotesis nol (Ho).

b. Berdasarkan perhitungan menggunakan koefisien korelasi (R) diperoleh nilai sebesar 0,616, hal ini memberikan makna bahwa hubungan variable pengawasan dengan efektivitas kerja karyawan kuat dan bernilai positif.

c. Dari hasil perhitungan koefisien determinasi diperoleh nilai $r^{2}=$ 0,417 . Hal ini berarti variabel efektivitas kerja karyawan dipengaruhi oleh variabel pengawasan hanya sebesar $41,7 \%$, sedangkan sisanya dipengaruhi oleh variabel lain yang tidak diteliti.

\section{Saran}

Sesuai dengan hasil penelitian yang telah dilakukan, maka penulis dapat mengemukakan beberapa saran sebagai berikut:

a. Terbukti pengawasan berpengaruh terhadap efektivitas kerja karyawan, maka hendaknya pimpinan lebih meningkatkan perannya dalam pengawasan, memotivasi dan koordinasi terhadap karyawannya.

b. Pengawasan harus dilakukan sesuai dengan keadaan yang terjadi pada perusahaan, karena ada sebagian jawaban responden tidak mencerminkan keadaan 
sesungguhnya yang terjadi di perusahaan.

c. Disamping faktor Pengawasan, factor-faktor lain yang mungkin dapat mempengaruhi disiplin kerja pegawai perlu diperhatikan.

\section{DAFTAR PUSTAKA}

Gibson, et al. 2005. Organisasi: Perilaku, Struktur dan Proses. Alih Bahasa: Nunuk Adriani. Jakarta: Erlangga.

Handoko, T. Hani. 2009. Manajemen Sumber Daya Manusia. Yogjakarta: BPFE.

Kadir. 2009. Perbedaan Motivasi Karyawan Honor dan PNS. [Online]. Tersedia: http://trainermuslim.com/perbed aan-motivasi-karyawan-honordan-pns.html. [5April 2013]

Siagian, P. Sondang. 2006. Kiat Meningkatkan Produktifitas Kerja. Jakarta. Rineka Cipta.

Steers, Richard M. 2005. Efektivitas Organisasi. Jakarta:Erlangga

Sugiyono. 2010. Statistika untuk Penelitian. Cetakan ke-16, CV. Alfabeta, Bandung.

Winardi. 2008.2 Manajemen Perkantoran dan Pengawasan, Bandung, CV. Mandar Maju. 